\title{
Pengaruh MOL Bekicot Terhadap Hasil Kacang Panjang (Vigna sinensis, L.) Pada Tanah Podsolik Merah Kuning
}

\author{
Herlina Kurniawati \\ Fakultas Pertanian Universitas Kapuas Sintang \\ e-mail: herlina_kurniawati@yahoo.com
}

\begin{abstract}
Abstrak: Meningkatkan produksi kacang panjang masih dapat diupayakan karena tanah yang masih cukup tersedia meskipun kondisi tanah kurang subur, namun melalui pemberian MOL Bekicot diharapkan dapat mengatasi kekurangan unsur hara pada tanah Podsolik Merah Kuning. Penelitian ini bertujuan untuk mengetahui pengaruh Mol Bekicot terhadap hasil kacang panjang pada tanah Podsolik Merah Kuning, dan mengetahui dosis Mol Bekicot yang menghasilkan hasil kacang panjang pada tanah Podsolik Merah Kuning. Percobaan ini menggunakan Rancangan Acak Kelompok dengan MOL Bekicot sebagai perlakuan yang terdiri dari lima taraf dan diulang lima kali yaitu: $b_{0}$ (tidak diberi Mol), $b_{1}\left(1 \mathrm{ml}\right.$ MOL Bekicot), $b_{2}$ (2 ml MOL Bekicot), $b_{3}$ (3 $\mathrm{ml}$ MOL Bekicot), dan $\mathrm{d}_{4}(4 \mathrm{ml}$ MOL Bekicot). Data hasil pengamatan dianalisis dengan analisis sidik ragam kemudian dilanjutkan dengan uji BNJ. Hasil penelitian diketahui bahwa MOL Bekicot berpengaruh nyata terhadap hasil tanaman kacang panjang pada tanah PMK, pengaruh ini diketahui melalui hasil analisis statistik terhadap peubah berat polong, tetapi pada peubah jumlah polong pemberian MOL Bekicot berpengaruh tidak nyata. Hasil analisis data diketahui bahwa pemberian $3 \mathrm{ml}$ MOL Bekicot menghasilkan berat polong tertinggi dengan berat rata-rata $0,76 \mathrm{~kg}$ per tanaman.
\end{abstract}

Kata Kunci : MOL Bekicot, hasil, kacang panjang, Podsolik Merah Kuning.

\section{PENDAHULUAN}

Mengkonsumsi sayuran penting untuk menjaga kesehatan termasuk mengkonsumsi kacang panjang karena komoditi ini merupakan salah satu sumber protein nabati yang cukup potensial. Menurut Haryanto, dkk. (2006:1), kacang panjang mengandung vitamin $\mathrm{A}, \mathrm{B}$, dan $\mathrm{C}$ terutama pada polong muda. Selain vitamin pada biji juga mengandung protein, lemak, dan karbohidrat.

Rendahnya produksi hasil pertanian khususnya tanaman hortikultura (kacang panjang) diduga karena terbatasnya pengetahuan petani tentang teknik budidaya yang baik, serta didukung oleh factor tanah yang kurang subur. Menurut Rosmarkam dan Yuwono (2002:32), selain unsur hara factor tanah juga sangat menentukan dalam keberhasilan budidaya tanaman. Beranjak dari pendapat tersebut sangatlah jelas bahwa tanah memegang peranan yang sangat penting dalam budidaya tanaman.

Tanah podsolik merah kuning atau lebih dikenal dengan tanah 
Podsolik Merah Kuning merupakan tanah yang sangat tercuci dan bahan organik rendah. Menurut Hardjowigeno (2003:221), tanah podsolik merah kuning berdasarkan klasifikasi USDA (United State Departement of Agronomy) masuk kedalam ordo ultisol dimana terjadi penimbunan liat di horizon bawah, besifat masam, kejenuhan basa pada kedalaman $180 \mathrm{~cm}$ dari permukaan tanah kurang dari $35 \%$. Pada kenyataannya tanah Podsolik Merah Kuning dapat dikatakan bahwa tanah yang bersifat marginal karena mengandung timbunan $\mathrm{Al}$ dan $\mathrm{Fe}$ yang cukup tinggi, serta unsur hara rendah sehingga dalam pengelolaannya diperlukan penambahan bahan organic dan pemberian pupuk yang tepat agar tanah menjadi produktif dan tidak rusak. Salah satu cara yang dapat dilakukan adalah dengan cara memberikan pupuk MOL Bekicot.

Bekicot digunakan sebagai bahan dasar pembuatan Mol sangat didukung dengan ketersediaan yang cukup banyak, serta proses pengolahannya yang mudah. Mol Bekicot mengandung unsur hara $\mathrm{K}, \mathrm{Mg}$ dan $S$ yang sangat diperlukan oleh tanaman kacang panjang dalam pertumbuhan dan hasil (Susetya,
2011:1). Mol juga dapat memperkaya unsur hara tanah, berperan sebagai perbaikan sifat fisik tanah, tata ruang udara tanah, mempertinggi daya ikat tanah terhadap zat hara sehingga tidak mudah larut oleh air hujan.

Penelitian ini bertujuan untuk 1) mengetahui pengaruh Mol Bekicot terhadap pertumbuhan dan hasil kacang panjang pada tanah Podsolik Merah Kuning; 2) mengetahui dosis Mol Bekicot yang menghasilkan pertumbuhan serta hasil kacang panjang pada tanah Podsolik Merah Kuning.

\section{METODOLOGI PENELITIAN}

\section{Metode Penelitian}

Percobaan ini menggunakan Rancangan Acak Kelompok dengan MOL Bekicot sebagai perlakuan yang terdiri dari lima taraf dan diulang lima kali yaitu:

$\mathrm{b}_{0}=$ tidak diberi MOL Bekicot (kontrol)

$b_{1}=1 \mathrm{ml}$ MOL Bekicot per liter air per bedengan

$\mathrm{b}_{2}=2 \mathrm{ml}$ MOL Bekicot per liter air per bedengan

$\mathrm{b}_{3}=3 \mathrm{ml}$ MOL Bekicot per liter air per bedengan

$\mathrm{b}_{4}=4 \mathrm{ml}$ MOL Bekicot per liter air per bedengan 
Jumlah tanaman percobaan dalam penelitian ini adalah 8 tanaman $\mathrm{x}$ 5 taraf MOL Bekicot x 5 ulangan $=200$ tanaman, sedangkan yang tanaman diamati adalah seluruh tanaman percobaan.

\section{Bahan dan Alat Penelitian}

Bahan serta alat yang diperlukan dalam penelitian ini terdiri dari:

1. Bahan

Bahan-bahan yang digunakan dalam penelitian ini adalah benih kacang panjang varietas $\mathrm{Kp}-1, \mathrm{MOL}$ Bekicot, Furadan 3G, Insektisida Decis 2.5 EC, Fungisida Bayfidan 250 EC.

\section{Alat}

Alat-alat yang digunakan dalam penelitian ini adalah cangkul, parang, gembor, kamera, alat tulis, ember plastik, botol plastik bekas air mineral dengan kapasitas isi 1,5 liter, selang plastik digunakan untuk sirkulasi udara, saringan, kamera, ,alat tulis, hand Sprayer, diperlukan untuk memberikan MOL pada tanaman, gelas ukur digunakan untuk menentukan dosis MOL Bekicot.

\section{Waktu dan tempat penelitian}

Penelitian ini dilaksanakan di Desa Baning Kota, Kecamatan Sintang Kabuapaten Sintang. Penelitian dimulai bulan Juni sampai Agustus 2017.

\section{HASIL DAN PEMBAHASAN}

\section{Hasil Penelitian}

A. Jumlah Polong

Data pengamatan yang telah direratakan dapat dilihat dalam Tabel 1.

Tabel 1. Rerata jumlah polong (polong)

\begin{tabular}{|c|c|c|c|c|c|c|c|}
\hline \multirow{2}{*}{ Perlakuan } & \multicolumn{5}{|c|}{ Ulangan } & \multirow{2}{*}{ Jumlah } & \multirow{2}{*}{ Rerata } \\
\hline & I & II & III & IV & V & & \\
\hline $\mathrm{b}_{0}$ & 24,00 & 25,00 & 29,00 & 37,00 & 15,50 & 130,50 & 26,10 \\
\hline$b_{1}$ & 31,00 & 26,00 & 23,00 & 34,00 & 22,50 & 136,50 & 27,30 \\
\hline$b_{2}$ & 27,00 & 23,00 & 24,00 & 44,00 & 24,50 & 142,50 & 28,50 \\
\hline$b_{3}$ & 30,00 & 32,00 & 29,00 & 35,00 & 25,50 & 151,50 & 30,30 \\
\hline $\mathrm{b}_{4}$ & 27,00 & 29,00 & 28,00 & 35,00 & 30,00 & 149,00 & 29,80 \\
\hline Total & 139,00 & 135,00 & 133,00 & 185,00 & 118,00 & 710,00 & 28,40 \\
\hline
\end{tabular}

Sumber: Data pengamatan, 2017. 
Data rerata hasil pengamatan dianalisis dengan analisis ragam yang jumlah polong seperti yang hasilnya ditampilkan dalam Tabel 2. diperlihatkan dalam Tabel 1. kemudian

Tabel 2. Analsisis ragam pengaruh MOL Bekicot terhadap jumlah polong (polong)

\begin{tabular}{llccccc}
\hline \multirow{2}{*}{ SK } & \multirow{2}{*}{ DB } & JK & KT & F-hitung & \multicolumn{2}{c}{ F-tabel } \\
\cline { 5 - 7 } & & & & & $\mathbf{0 , 0 5}$ & $\mathbf{0 , 0 1}$ \\
\hline Ulangan & 4 & 512,8 & 128,2 & $8,85^{* *}$ & 3,01 & 4,77 \\
Perlakuan & 4 & 60,4 & 15,1 & $1,04^{\text {tn }}$ & 3,01 & 4,77 \\
Galat & 16 & 231,80 & 14,4875 & & & \\
\hline \multicolumn{1}{c}{ Total } & $\mathbf{2 4}$ & $\mathbf{8 0 5 , 0 0}$ & & $\mathbf{k k}=$ & $\mathbf{1 3 , 4 0 \%}$ \\
\hline Sumber & $:$ Data analisis, 2017 & & \\
Keterangan & $:$ th = pengaruh tidak nyata pada taraf kepercayaan $95 \%$ \\
& $* *=$ pengaruh sangat nyata pada taraf kepercayaan $99 \%$
\end{tabular}

Hasil analisis ragam pada Tabel

2 memperlihatkan bahwa perlakuan

MOL Bekicot berpengaruh tidak nyata terhadap jumlah polong per tanaman,

karena itu tidak dilakukan uji lanjut.
B. Berat Polong

Data hasil pengamatan yang telah direratakan ditampilkan dalam Tabel 3.

Tabel 3. Rerata berat polong (kg)

\begin{tabular}{cccccccc}
\hline \multirow{2}{*}{ Perlakuan } & \multicolumn{7}{c}{ Ulangan } \\
\cline { 2 - 6 } & I & II & III & IV & V & \multirow{2}{*}{ Jumlah } & Rerata \\
\hline $\mathrm{b}_{0}$ & 0,42 & 0,53 & 0,67 & 0,39 & 0,34 & 2,35 & 0,47 \\
$\mathrm{~b}_{1}$ & 0,54 & 0,65 & 0,52 & 0,69 & 0,52 & 2,92 & 0,58 \\
$\mathrm{~b}_{2}$ & 0,52 & 0,47 & 0,53 & 0,53 & 0,54 & 2,58 & 0,52 \\
$\mathrm{~b}_{3}$ & 0,74 & 0,76 & 0,71 & 0,65 & 0,95 & 3,81 & 0,76 \\
$\mathrm{~b}_{4}$ & 0,56 & 0,69 & 0,76 & 0,90 & 0,94 & 3,85 & 0,77 \\
\hline Total & $\mathbf{2 , 7 8}$ & $\mathbf{3 , 1 0}$ & $\mathbf{3 , 1 9}$ & $\mathbf{3 , 1 5}$ & $\mathbf{3 , 2 8}$ & $\mathbf{1 5 , 5 0}$ & $\mathbf{0 , 6 2}$ \\
\hline
\end{tabular}

Sumber: Data pengamatan, 2017.

Data rerata hasil pengamatan berat polong seperti yang ditampilkan dalam Tabel 3 selanjutnya dianalisis dengan analisis ragam yang hasilnya diperlihatkan dalam Tabel 4. 
Tabel 4. Analisis ragam pengaruh MOL Bekicot terhadap berat polong (kg)

\begin{tabular}{|c|c|c|c|c|c|c|}
\hline \multirow{2}{*}{ SK } & \multirow{2}{*}{ DB } & \multirow{2}{*}{ JK } & \multirow{2}{*}{ KT } & \multirow{2}{*}{ F-hitung } & \multicolumn{2}{|c|}{ F-tabel } \\
\hline & & & & & 0,05 & 0,01 \\
\hline Ulangan & 4 & 0,028675 & 0,00716875 & $0,53^{\text {tn }}$ & 3,01 & 4,77 \\
\hline Perlakuan & 4 & 0,38533 & 0,0963325 & $7,10^{* * *}$ & 3,01 & 4,77 \\
\hline Galat & 16 & 0,22 & 0,013560625 & & & \\
\hline Total & 24 & 0,63 & & $\mathbf{k k}=$ & $18,78 \%$ & \\
\hline
\end{tabular}

Sumber : Data analisis, 2017.

Keterangan : tn = pengaruh tidak nyata pada taraf kepercayaan $95 \%$ $* *=$ pengaruh sangat nyata pada taraf kepercayaan $99 \%$

Data hasil analisis ragam pada

Tabel 4 menunjukkan bahwa perlakuan

MOL Bekicot berpengaruh sangat nyata terhadap berat polong per tanaman, selanjutnya agar diketahui taraf pemberian MOL Bekicot yang menghasilkan berat polong tertinggi dilakukan dengan uji BNJ seperti pada Tabel 5.

Tabel 5. Uji BNJ MOL Bekicot terhadap berat polong (kg)

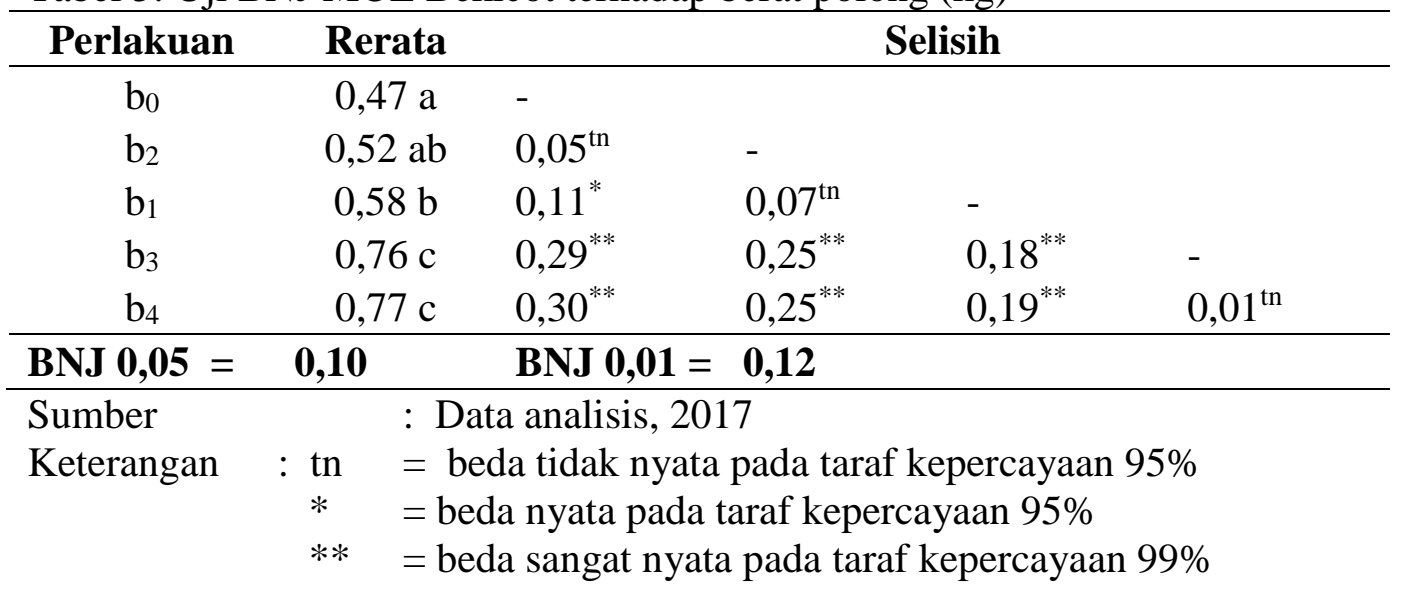

Hasil uji BNJ menunjukkan bahwa tanaman yang diberi $4 \mathrm{ml} \mathrm{MOL}$ Bekicot menghasilkan berat polong yang tidak lebih berat dari yang dihasilkan oleh tanaman yang diberi 3 ml MOL Bekicot, namun lebih berat dari yang dihasilkan oleh tanaman dengan diberi $1 \mathrm{ml}$ MOL Bekicot, $2 \mathrm{ml}$ MOL Bekicot, dan tanaman yang tidak diberi MOL Bekicot. Tanaman yang diberi $1 \mathrm{ml}$ MOL Bekicot menghasilkan berat polong yang tidak lebih tinggi dari yang dihasilkan oleh tanaman dengan pemberian $2 \mathrm{ml}$ MOL Bekicot, tetapi lebih berat dari polong tanaman tanpa diberi MOL Bekicot. Pada tanaman yang diberi $2 \mathrm{ml}$ MOL Bekicot menghasilkan polong yang tidak lebih 
berat dari yang dihasilkan tanaman tanpa pemberian MOL Bekicot.

\section{Pembahasan}

Hasil analisis ragam diketahui bahwa pemberian MOL Bekicot berpengaruh nyata terhadap berat polong, tetapi berpengaruh tidak nyata terhadap jumlah polong. Pengaruh tidak nyata pemberian MOL Bekicot terhadap jumlah polong diduga karena unsur hara yang tersedia dalam tanah dapat memenuhi kebutuhan tanaman dalam membentuk polong kacang panjang, tetapi polong yang dihasilkan dari tanaman tanpa diberi MOL dengan yang diberi secara visual berbeda jika dilihat dari ukuran polong baik panjang maupun besarnya polong.

Pemberian MOL Bekicot berpengaruh sangat nyata terhadap berat polong diduga karena peran dari Aspergilus niger dalam melarutkan fosfat yang terikat oleh $\mathrm{Al}$ dan $\mathrm{Fe}$ sehingga menjadi tersedia bagi tanaman. Elfianti (2005:4) menyatakan bahwa Aspergilus niger berperan dalam membebaskan unsur $\mathrm{P}$ dari ikatan $\mathrm{Al}$ dan Fe, terutama pada tanah-tanah mineral yang kekurangan bahan organik. Terbebasnya unsur $P$ ini memungkinkan pembentukan bunga dan buah (polong) menjadi lebih baik, serta pengisian biji-bijian dalam polong menjadi optimal yang pada akhirnya meningkatkan berat polong pada tanaman kacang panjang. Setyamidjaya (1986:16) menyatakan bahwa Fosfor berperan penting dalam memacu pertumbuhan dan pembentukan bunga dan pemasakan buah, dan biji sebagai bahan penyusun inti sel, lemak dan protein dalam tanaman.

Hasil uji BNJ diketahui bahwa pemberian MOL Bekicot $4 \mathrm{ml}$ menghasilkan berat polong yang tidak lebih tinggi dari polong yang dihasilkan oleh tanaman yang diberi $3 \mathrm{ml}$. Hal ini diduga karena unsur hara yang terbebaskan melalui bantuan mikroba Aspergilus niger dari pemberian $3 \mathrm{ml}$ MOL sudah mampu memenuhi kebutuhan tanaman dalam meningkatkan berat polong tanaman kacang panjang, sehingga pada pemberian $4 \mathrm{ml}$ tidak memberikan kontribusi yang besar dalam meningkatkan berat polong.

\section{KESIMPULAN DAN SARAN}

\section{Kesimpulan}

1. MOL Bekicot berpengaruh nyata terhadap peubah berat polong tanaman kacang panjang pada tanah 
Podsolik Merah Kuning, tetapi pada peubah jumlah polong pemberian MOL Bekicot berpengaruh tidak nyata.

2. Hasil analisis data diketahui bahwa pemberian $3 \mathrm{ml}$ MOL Bekicot menghasilkan berat polong tertinggi dengan berat rata-rata $0,76 \mathrm{~kg}$ per tanaman.

\section{Saran}

1. Untuk meningkatkan pertumbuhan dan hasil tanaman kacang panjang pada tanah Podsolik Merah Kuning, MOL Bekicot dapat diberikan.

2. Melaui hasil penelitian ini dosis MOL Bekicot yang dianjurkan untuk meningkatkan hasil kacang panjang adalah $3 \mathrm{ml}$.

\section{DAFTAR PUSTAKA}

Andiani. 2013. MOL. Balai Pelatihan Penyuluhan Pertanian. Jakarta.

Badan Pusat Statistik Kalimantan Barat. 2015. Kalimantan Barat Dalam Angka. Badan Pusat Statistik Kalimantan Barat. Pontianak.

BP4K Sukabumi. 2013. Panduan Pembuatan MOL. BP4K Sukabumi. Sukabumi.

Bucman, H.O., Brady, N.C.1982. Ilmu Tanah diterjemahkan oleh Soegiman. Bhatara Karya Aksara. Jakarta.
Direktorat Tanaman Pangan. 2011. Panduan Budidaya Tanaman Pangan. Direktorat Tanaman Pangan Departemen Pertanian Republik Indonesia. Jakarta.

Elfiati, D. 2005. Peranan Mikroba Pelarut Fosfat Terhadap Pertumbuhan Tanaman. Jurusan Kehutanan Fakultas Pertanian Universitas Sumatera Utara Medan dalam e-USU Repisitory.

Gaspersz, V., 1994. Metode Perancangan Percobaan. Armico. Bandung.

Hardjowigeno, S. 1992. Klasifikasi Tanah dan Pedogenesis. Akademika Pressindo. Jakarta.

Hardjowigeno, S. 2003. Ilmu Tanah. Akademika Pressindo. Jakarta.

Haryanto, E., Suhartini, T., dan Rahayu, E. 2006. Budidaya Kacang Panjang. Penebar Sawadaya. Jakarta.

Lindung. $2015 . \quad$ Teknologi Mikroorganisme EM4 dan MOL. Balai Pelatihan Penyuluhan Jambi. Jambi.

Notohadiprawiro, T. 1986. Ultisol, Fakta dan Implementasi Pertaniannya. Buletin Pusat Penelitian Marihat No. 6. Tahun 1986. Repro: Ilmu Tanah Universitas Gajah Mada. Yogyakarta.

Pirngadi K., 2009. Peran Bahan Organik dalam Peningkatan Produksi Padi Berkelanjutan Mendukung Ketahanan Pangan 
Pengaruh MOL Bekicot Terhadap Hasil Kacang Panjang (Vigna sinensis, L.) Pada Tanah Podsolik Merah Kuning

Nasional. Pengembangan Inovasi Pertanian 2(1) : 48-64.

Pitojo. 2006. Budidaya Kacang Panjang dan Buncis. Penebar Swadaya. Jakarta.

Prasetyo, B.H., dan Suriadikarta, D.A. 2006. Karakteristik, Potensi, dan Teknologi Pengelolaan Tanah Ultisol Untuk Pengembangan Pertanian Lahan Kering di Indonesia. Jurnal Litbang Pertanian, Nomor: 25 edisi ke-2. Bogor.

Rosmarkam, A. dan Yuwono, N.W. 2002. Ilmu Kesuburan Tanah. Kanisius. Yogyakarta.

Rukmana, R. 2006. Kacang Panjang. Kanisius. Yogyakarta.
Setyamidjaja, D., 1986. Pupuk dan Pemupukan. Simplex. Jakarta.

Suhastyo, A.S., I. Anas., D.A. Santosa., Y. Lestari. 2013. Studi Mikrobiologi Dan Sifat Kimia Mikroorganisme Lokal (MOL) Yang Digunakan Pada Budidaya Padi Metode SRI (System of Rice Intensification). Sainteks No. 29. Vol. X. November 2013.

Sukamto, M.H. 2008. Kacang Panjang, Biji Hitam Super, Rumbai Eksotis yang Laris. Artikel Sahabat Petani. Lampung.

Sunarjono, H. 2003. Bertanam Kacang Sayur. Penebar Swadaya. Jakarta.

Sustetya. 2011. Mikroorganisme Lokal. Balai Pelatihan Penyuluhan Pertanian. Jakarta. 